\title{
Fuzzy comprehensive evaluation of five forage shrubs in Mu Us sandland, China
}

\author{
Dongmei $\mathrm{Xu}^{1,2^{*}}$, Xinzhong $\mathrm{Xu}^{3}$, Hongbin $\mathrm{Ma}^{1,2}$, Yan Shen ${ }^{1,2}$ \\ ${ }^{1}$ College of Agronomy, Ningxia University, Yinchuan, China; ${ }^{*}$ Corresponding Author: nxxudongmei@163.com \\ ${ }^{2}$ Breeding Base of State Key Laboratory for Preventing Land Degradation and Ecological Restoration, Ningxia University, Yinchuan, \\ China \\ ${ }^{3}$ College of Mathematics and Computer Science, Ningxia University, Yinchuan, China
}

Received 7 October 2011; revised 18 November 2011; accepted 19 December 2011

\section{ABSTRACT}

Chemical compositions during different growing periods, preference and in vitro digestibility at the post-fruiting period of five psammophyte shrubs, which include Caragana intermedia, Caragana korshinskii, Hedysarum scoparium, Hedysarum laeve, Salix psammophylla were determined. The nutritive values were synthetically evaluated in terms of chemical composition, preference and in vitro digestibility through fuzzy multifactorial model. The crude protein (CP) concentrations of the five shrubs had the tendency to decrease with growing stage, the peak values of $C$. intermedia, $C$. korshinskii and S. psammophylla appeared at blooming period and those of $H$. scoparium and $H$. laeve appeared at vegetative period. The neutral-detergent fiber (NDF), acid-detergent fiber (ADF) and lignin concentrations of $C$. intermedia, $C$. korshinskii and S. psammophylla were all decreased before post-fruiting period and then increased significantly; while the variation tendency of those of $H$. scoparium and $H$. leave were alike, and the lowest NDF, ADF and lignin concentrations were at vegetative period or post-fruiting period. The five shrubs can be used as feedstuffs, the synthetical nutritive value at the post-fruiting period were high in order of $C$. intermedia, $H$. scoparium, $H$. laeve, $C$. korshinskii and S. psammophylla. Considering the characteristics of growth and nutritive value, the optimum time to use these shrubs as feedstuffs is the post-fruiting period in autumn. Among the five shrubs, $C$. intermedia is the best as feedstuff for raising the production of livestock.

Keywords: Chemical Composition; Fuzzy Multifactorial Model; Vitro Digestibility; Preference;
Psammophyte Shrubs

\section{INTRODUCTION}

The Mu Us sandy land, an ecotone comprised of steppe, desert-steppe and steppe-desert, is located in the Ordos plateau, covers an area of approximately 40000 $\mathrm{km}^{2}$, and is one of the twelve well-known sandy deserts in China [1]. It is characterized by sparse precipitation, frequent drought and poor soil nutrients [2-4]. The local herbaceous coverage is especially low usually [4]. Provision of adequate quantities of inexpensive high-quality forage is a major challenge in the development of livestock production systems in this region.

Psammophyte shrubs are tolerant to drought, barren ground, and wind erosion, grow rapidly and have well developed root systems. These shrubs have become the dominant species by ecological restoration and play an important role in the control of land degradation and desertification, as well as in grassland construction [5].

With the advance of sand fixation, large areas of sandy grassland mainly with psammophyte shrubs have been established in Mu Us sandy land based on their roles in reducing wind speed and soil erosion and improving ecological environments [6]. Since psammophyte shrubs have high biomass production [7] and also have been widely used as feedstuffs [8], they can play an important role in the nutrition of grazing animals during a withered season and a droughty year. The ultimate aim is effective utilization of sandy land resources to acquire optimum balance of ecological and economic benefits, to realize the sustainability of ley farming and to raise the production of livestock simultaneously. Evaluations of the feeding value of psammophyte shrubs provide a sound basis for determining nutritional feasibility of utilizing them. Some existing reports have indicated that psammophyte shrubs are promising feedstuffs based on their biomass and chemical composition [9-11]. Several researchers have investigated the dynamics of nutrient 
contents of psammophyte shrubs [8,12-13]. However, these shrubs have not been fully evaluated in terms of concurrent estimation of chemical composition, preference and digestibility.

The objective of this paper is to determine the dynamics of nutrient content of different growth periods for several psammophyte shrubs in Mu Us sandy land, and to evaluate synthetically the nutritive value at the postfruiting period in terms of chemical composition, preference and in vitro digestibility.

\section{MATERIALS AND METHODS}

\subsection{Study Area}

The study area is located at the southwest edge of $\mathrm{Mu}$ Us sandy land in Yanchi, Ningxia, China (37 $52^{\prime} 30^{\prime \prime}$ $37^{\circ} 57^{\prime} 30^{\prime \prime} \mathrm{N}$ and $\left.107^{\circ} 26^{\prime} 15^{\prime \prime}-107^{\circ} 33^{\prime} 45^{\prime \prime} \mathrm{E}\right)$ with an elevation of $1300 \mathrm{~m}-1360 \mathrm{~m}$. Mean annual temperature is $8.1^{\circ} \mathrm{C}$, the coldest and warmest monthly mean temperatures are $-9.3^{\circ} \mathrm{C}$ in January and $22.0^{\circ} \mathrm{C}$ in July respectively. Wind season is mainly in April and May, average wind speed reaches $3-4 \mathrm{~m} / \mathrm{s}$. Mean annual precipitation is $295 \mathrm{~mm}$ and about 70 percent concentrated from June to September. Mean annual potential evaporation is about $2710 \mathrm{~mm}$, frost-free period is 148 days. This area is a transition zone between semiarid and arid climate. Rainfall is irregular and characterized by extreme seasonal and annual variability (From Weather Bureau in Yanchi County). Frequent drought is a major limiting factor for growth of sandy land vegetation (The environmental conditions for the experimental year and the long term are shown in Figure 1). The regional vegetation cover belongs to desert-steppe type. The major plant species in this area are Artemisia sphaerocephala, Caragana intermedia, Psammochloa villosa, Salix psammophylla, Corispermum tylocarpum, Hedysarum scoparium, H. laeve, Artemisia ordosica, Sophora alopecuroides, Cynanchum komarovii, Pennisetum centrasiaticum, Setaria viridis, Oxytropis aciphylla, Leymus secalinus, $\mathrm{Ni}$ traria tangutorum, Kalidium gracile, Achnatherum splendens. In the past few years, with the development of sand fixation, large areas of artificial and semi-natural grassland mainly included psammophyte shrubs have been established.

\subsection{Sample Collection and Preparation}

We selected five species of shrubs Caragana intermedia, Caragana korshinskii, Hedysarum scoparium, Hedysarum laeve and Salix psammophylla which are abundant and widespread in Mu Us sandy land at the same location. In Mu Us sandyland, these shrubs provide essential food especially in autumn and winter for grazing animals, and also can be made into haycube to be used as
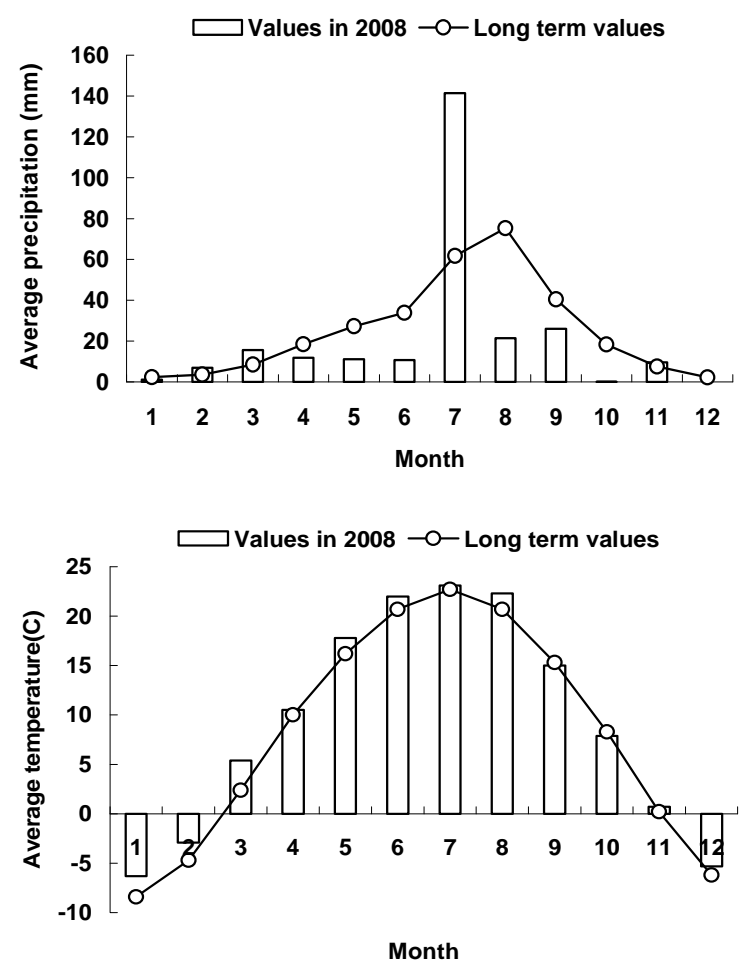

Figure 1. Mean monthly rainfall and temperature for the long-term and for 2008.

supplemental feed in winter. The shrubs were established with five replications of each species in a random block design and grew under natural conditions. We randomly selected 15 5-year-old individuals about $2 \mathrm{~m}$ height of each species in each replication, and determined the phenological periods and harvesting dates of the shrubs by field observing. One fourth of the total shoots of less than $3 \mathrm{~mm}$ diameter with leaves (it was revealed by investigation that they are the parts of plants most likely to be chosen by sheep and goats [14]) of the 15 assigned plants from each plot replication for each species were harvested by hand at vegetative period (Apr. 20, 2008 for C. intermedia and C. korshinskii, May 20, 2008 for $H$. scoparium and H. laeve and Mar. 20, 2008 for S. psammophylla), blooming period (May 20, 2008 for C. intermedia and C. korshinskii, Jul. 20, 2008 for H. scoparium and H. laeve and Apr. 20, 2008 for S. psammophylla), fruiting period (Jun. 20, 2008 for $C$. intermedia and $C$. korshinskii, Aug. 20, 2008 for H. scoparium and H. laeve and May 20, 2008 for S. psammophylla), post-fruiting period (Sep. 20, 2008) and withering period (Dec. 20, 2008 and Feb. 20, 2009, respectively). The 15 samples obtained per species from the same plot replication for the same period were cut short, mixed to give a single compound sample, and the analytical sample of $1000 \mathrm{~g}$ were took out by using quartation. The analytical samples were dried in an oven at $60^{\circ} \mathrm{C}$ to constant weight and ground to pass through 1-mm screen using a laboratory 
mill prior to laboratory analysis [15].

For comparison, samples of Medicago sativa, Achnatherum splendens and stalks of Zea mays which present respectively high, moderate and low quality of local forages were subjected to the same range of analyses as the five species of shrubs at the post-fruiting period.

\subsection{Chemical Analyses}

Kjeldahl nitrogen $(\mathrm{N})$ was analyzed according to standard procedures, crude protein (CP) concentration was computed as $\mathrm{N}$ concentration $\times 6.25$ [15]. Neutral-detergent fiber (NDF), acid-detergent fiber (ADF) and lignin were determined by the methods of Van Soest [16].

\subsection{Determination of in Vitro Digestibility}

In vitro dry matter digestibility (IVDMD) and in vitro organic matter digestibility (IVOMD) of the five shrubs for the post-fruiting period were determined by the twostage technique of Tilley and Terry [17] using rumen fluid of Tan sheep. Eight female Tan sheep, each with a permanent rumen cannula, belonging to the flocks of the research farm of Ningxia University were used. The sheep were 2 years of age and the mean body weight was $32.6 \pm 1.4 \mathrm{~kg}$. They were housed in individual pens $(3 \mathrm{~m}$ $\times 2.5 \mathrm{~m}$ ), fed with alfalfa hay and concentrate supplement and had free access to water for a 11 day period before collection of the rumen fluid for the in vitro incubations. On day 12 of the feeding period a $200 \mathrm{ml}$ rumen fluid sample was extracted from each animal via the cannula. We mixed the fluid contents from different sheep for determining in vitro digestibility

\subsection{Determination of Preference}

For determining preference at the post-fruiting period, five Tan-sheep (average $35.2 \pm 1.6 \mathrm{~kg}$ of body weight and grazing on grasslands before the experiment) were housed in small individual pens $(250 \mathrm{~cm} \times 200 \mathrm{~cm})$ and fed twice daily (in the morning and in the afternoon) with $4 \mathrm{~kg} /$ head of fresh twigs less than 3 diameter and leaves of each species (including M. sativa, A. splendens and Z. Mays) put separately into different lattice of the trough at the same time. An hour later, the intake of each plant was recorded. This was conducted every other day for 2 consecutive days, and repeated five times per animal and varied the positions of the different plants in the troughs each time. Preference index $\left(P_{i}\right)$ was calculated according to the equation [18]:

$$
P_{i}=\sum_{k=1}^{n} \frac{D_{i} k}{R A_{i} k} / n
$$

where $D_{i}$ is the weight percentage of $i$ plant in ingested plants, $R A_{i}$ is the weight percentage of $i$ plant in provided plants, $k$ is the time of experimental.

\subsection{Statistical Analyses}

The mean and standard error values for each parameter were analyzed by 1-way analysis of variance (ANOVA) following Tukey's multiple range test obtained using SPSS12.0 (SPSS, Chicago, IL, USA) software to determine the statistical differences among species and among growth periods.

\subsection{Estimation of Feeding Value}

We selected the post-fruiting period and evaluated the feeding value of the five shrubs through fuzzy multifactorial model. The reason for selecting this period was because of the restriction of shrubs to withstand grazing. Forestry scholars suggested that it was feasible in late autumn to use shrubs as feedstuffs when they stopped growing gradually, at this time, the five shrubs were all at post-fruiting period [14]. Moreover, it was convenient for comparison of each other simultaneously.

Considering that it's not comprehensive to evaluate the feeding value of a kind of plant by using single factor or isolated multiple factors, we applied fuzzy transformation principle and maximum subordination principle, choosing those factors related to feeding value of forages and making a comprehensive evaluation.

\subsubsection{Model of Fuzzy Comprehensive Evaluation System}

Fuzzy comprehensive evaluation refers to the overall evaluation of a thing or a phenomenon affected by multiple factors, and then gives the evaluated thing or phenomenon a nonnegative evaluation value [19].

This model defines a grading level set of $v=$ \{grading level $1,2, \cdots, m\}$ and a factor set of $U=\{$ factor $1,2, \cdots$, $n$ \}. A membership vector $R_{i}=\left(r_{i 1}, r_{i 2}, \cdots, r_{i m}\right)$, developed to evaluate the contribution of factor $i$ to the various grading levels can be considered as a fuzzy subset on the grading level set $v$. According to this model, if $r_{i j}$ represents the membership $\mu_{R}\left(\mathrm{U}_{i}, \mathrm{~V}_{j}\right)$ of the contribution of factor $i$ on quality level $j$, then for $n$ factors and $m$ grading levels, the fuzzy transformation matrix $R$ can be written as:

$$
R=\left[\begin{array}{c}
R_{1} \\
R_{2} \\
\vdots \\
R_{n}
\end{array}\right]=\left[\begin{array}{cccc}
r_{11} & r_{12} & \cdots & r_{1 m} \\
r_{21} & r_{22} & \cdots & r_{2 m} \\
\vdots & \vdots & \vdots & \vdots \\
r_{n 1} & r_{n 2} & \cdots & r_{n m}
\end{array}\right]
$$

The membership $\mu$ is not defined arbitrarily, but by the expertise, knowledge, experience, experimental results, etc., available about the system [20].

To make an acceptable fuzzy evaluation, we may as- 
sign each element in the factor set $U$, a weighting factor based on the expertise of judges or experimental results.

The weighting factor vector $A$ then is a fuzzy subject of factor set $U$.

$$
A=\left(a_{1}, a_{2}, \cdots, a_{n}\right), a_{i} \geq 0, \sum_{i=1}^{n} a_{i}=1
$$

The fuzzy comprehensive evaluation process is a fuzzy transformation process from a weighting factor vector to a comprehensive grading vector $B$ as given below:

$$
\begin{aligned}
B & =A \cdot R=\left(a_{1}, a_{2}, \cdots, a_{n}\right) \cdot\left[\begin{array}{cccc}
r_{11} & r_{12} & \cdots & r_{1 m} \\
r_{21} & r_{22} & \cdots & r_{2 m} \\
\vdots & \vdots & \vdots & \vdots \\
r_{n 1} & r_{n 2} & \cdots & r_{n m}
\end{array}\right] \\
& =\left(b_{1}, b_{2}, \cdots, b_{m}\right)
\end{aligned}
$$

\subsubsection{Selection of Assessment Factors for Fuzzy Comprehensive Evaluation}

According to the characters of shrubs and the contribution of each factors to feeding value, we selected CP, $\mathrm{ADF}$ at the post-fruiting period, preference index, grazing seasons and IVOMD as assessment factors. Because each assessment factors has its own level of importance in feeding function, weighting coefficient and quantitative grade standards for each assessment factor (Figure 2, Table 1) were determined by the expertise.

\subsubsection{Fuzzy Comprehensive Evaluation of the Nutritive Value for the Shrubs}

Based on the traits of the appraisal for feeding value of forages, we took the following set of grading level:

$v=\{$ lowest, lower, low, moderate, high, higher, highest $\}$

$$
=\left\{\phi_{1}, \phi_{2}, \phi_{3}, \phi_{4}, \phi_{5}, \phi_{6}, \phi_{7}\right\}
$$

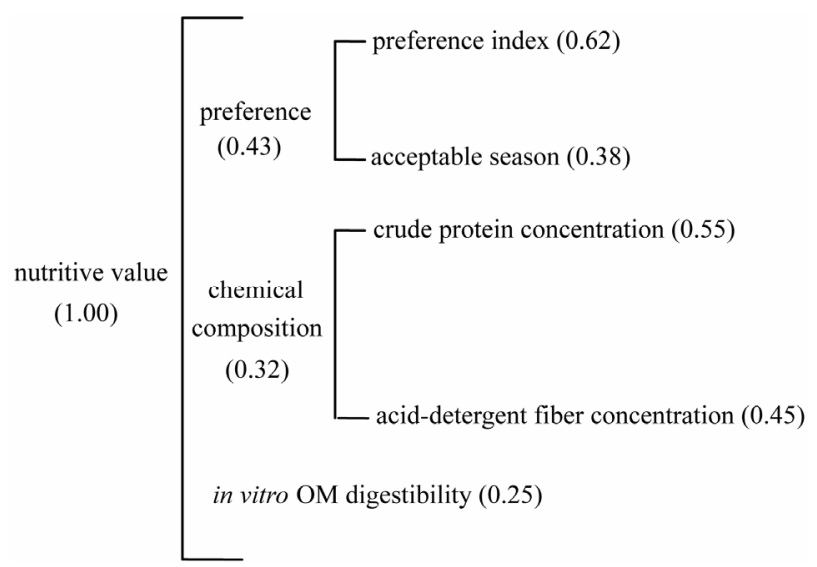

Figure 2. Factorial relationships and their weighting coefficients (numbers in the brackets) for the fuzzy multifactorial model. where

$$
\begin{aligned}
& \Phi i(x)=\left\{\begin{array}{l}
\max \left\{0,1-12\left(x-\frac{i-1}{6}\right)\right\}, x \in(0,1) \\
0, x \in(0,1)
\end{array}\right. \\
& (i=1,2, \cdots, 7)
\end{aligned}
$$

$\Phi 1, \Phi 2, \cdots, \Phi 7$ are truth values of standard language. Appraisal grades of the shrubs can be determined using results of comprehensive judgment values. To simplify the calculation of peak values, we suggested the following method [21]:

$\Phi=$

$$
\left[\begin{array}{l}
\phi 1 \\
\phi 2 \\
\phi 3 \\
\phi 4 \\
\phi 5 \\
\phi 6 \\
\phi 7
\end{array}\right]=\left[\begin{array}{lllllll}
0.65 & 0.35 & 0 & 0 & 0 & 0 & 0 \\
0.35 & 0.40 & 0.25 & 0 & 0 & 0 & 0 \\
0 & 0.35 & 0.40 & 0.25 & 0 & 0 & 0 \\
0 & 0 & 0.30 & 0.40 & 0.30 & 0 & 0 \\
0 & 0 & 0 & 0.27 & 0.40 & 0.33 & 0 \\
0 & 0 & 0 & 0 & 0.25 & 0.40 & 0.35 \\
0 & 0 & 0 & 0 & 0 & 0.35 & 0.65
\end{array}\right]
$$

Then result of comprehensive evaluation on feeding value of a certain species of shrub was:

$$
B=A \cdot R=A \cdot \Phi=\left(b_{1}, b_{2}, \cdots, b_{7}\right)
$$

According to maximum subordination principle, we chose $v_{i}$ which corresponded to the largest $b_{i}$ as the evaluating result.

The comprehensive evaluation value $(E V)$ was:

$$
E V=A \cdot R \cdot\left[\begin{array}{l}
1 \\
2 \\
3 \\
4 \\
5 \\
6 \\
7
\end{array}\right]=A \cdot \Phi \cdot\left[\begin{array}{l}
1 \\
2 \\
3 \\
4 \\
5 \\
6 \\
7
\end{array}\right]
$$

$E V$ value shows that the comprehensive judgment value corresponding to comprehensive grading vector $B$. Thus, we may make an objective grade evaluation for different species of the shrubs.

\section{RESULTS AND DISCUSSION}

\subsection{Dynamics of Nutrient Concentration of the Five Shrubs}

Chemical compositions of the five shrubs at different growth periods are presented in Figure 3. The CP concentrations of the 5 shrubs declined gradually from the blooming period to withered period. S. psammophylla, $C$. 
Table 1. Quantitative grade standard for comprehensive evaluation (except upper limit).

\begin{tabular}{|c|c|c|c|c|c|}
\hline$\Phi \mathrm{i}$ & Preference Index & Acceptable Seasons & CP Concentration & ADF Concentration & IVOMD \\
\hline$\Phi 7$ & $>1.50$ & four seasons & $>200$ & $<300$ & $>740$ \\
\hline$\Phi 6$ & $1.25-1.50$ & four seasons & $150-200$ & $300-340$ & $650-740$ \\
\hline$\Phi 5$ & $1.00-1.25$ & growing seasons & $100-150$ & $340-380$ & $570-650$ \\
\hline$\Phi 4$ & $0.75-1.00$ & growing seasons & $60-100$ & $380-420$ & $480-570$ \\
\hline Ф3 & $0.50-0.75$ & autumn, winter & $40-60$ & $420-460$ & $390-480$ \\
\hline$\Phi 2$ & $0.25-0.50$ & autumn & $30-40$ & $460-500$ & $310-390$ \\
\hline$\Phi 1$ & $<0.25$ & less than two months & $<30$ & $>500$ & $<300$ \\
\hline
\end{tabular}

$\dagger$ Units of CP, ADF concentrations and IVOMD were $\mathrm{g} \cdot \mathrm{kg}^{-1} \mathrm{DM}$.

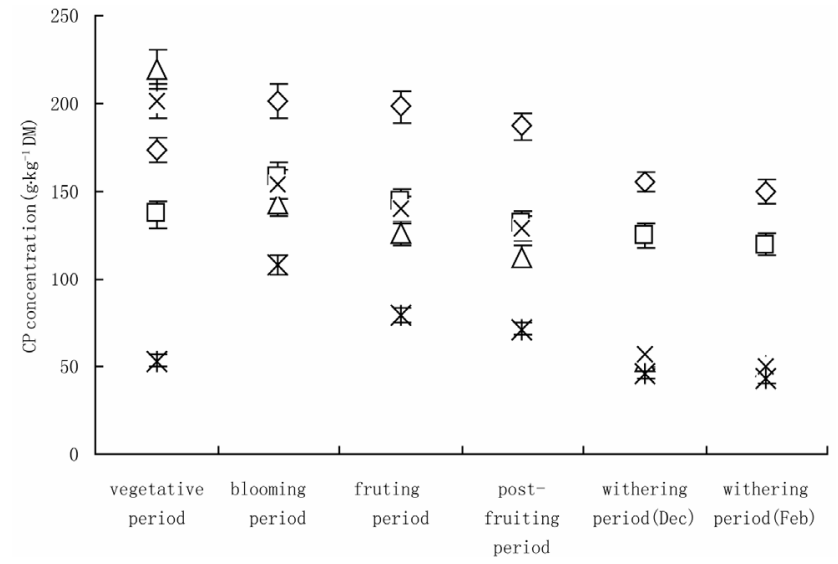

(a)

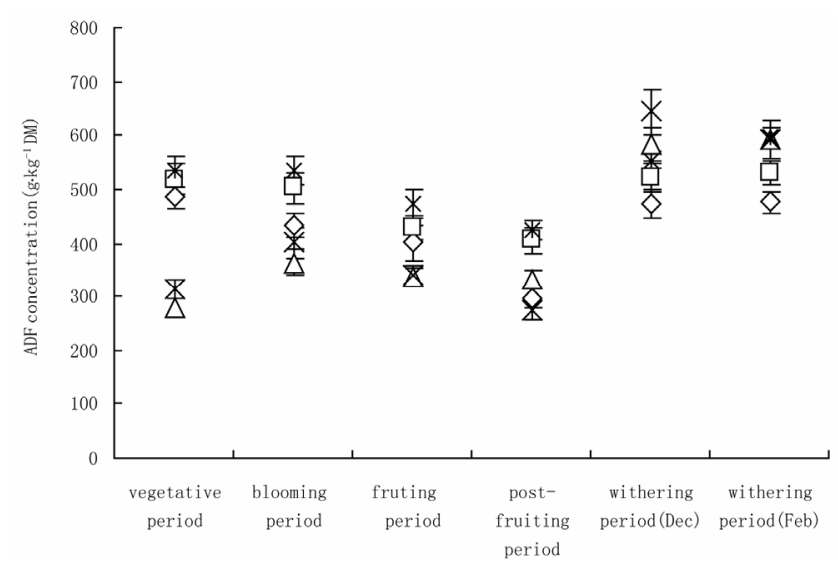

(c)

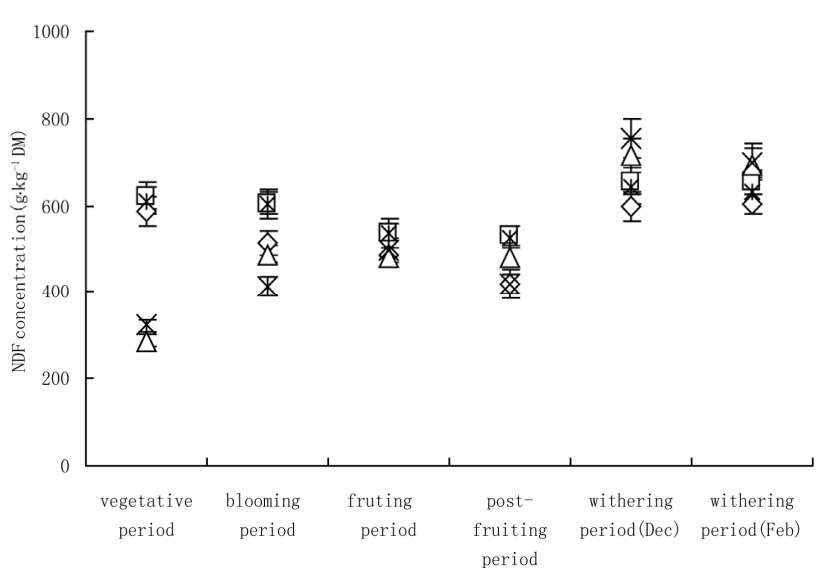

(b)

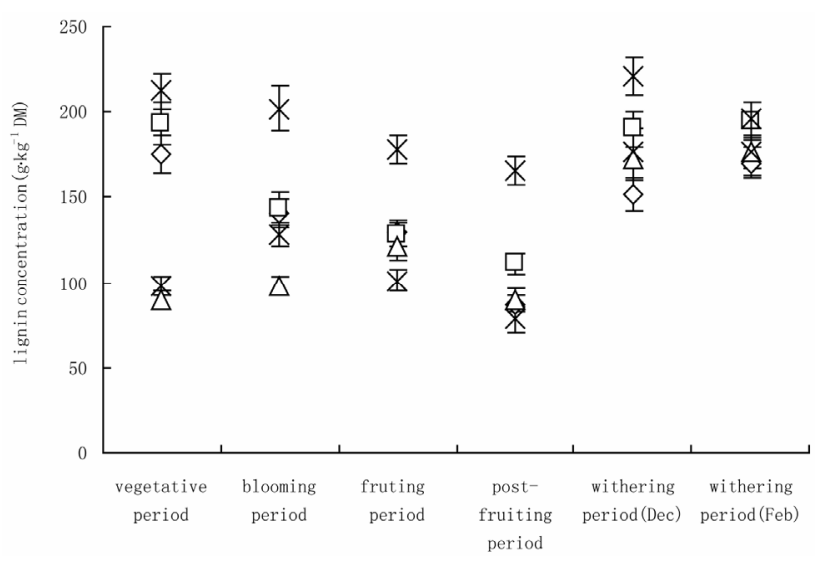

(d)

Figure 3. Dynamics of CP (a), NDF (b), ADF (c) and lignin (d) concentration of the five shrubs. $\diamond$, Caragana intermedia; $\square$, Caragana korshinskii; $\triangle$, Hedysarum scoparium; $\times$, Hedysarum laeve; *, Salix psammophyla.

intermedia and C. korshinskii had similar trends, the greatest $\mathrm{CP}$ concentrations were at blooming period; for $H$. scoparium and $H$. laeve, the greatest CP concentrations were at vegetative period. Among the five shrubs, $\mathrm{CP}$ concentration of $C$. intermedia was the highest and $S$. psammophylla was the lowest. The NDF, ADF and lignin concentrations for $C$. intermedia, $C$. korshinskii and $S$. psammophylla all decreased from vegetative period to the post-fruiting period, thereafter they increased significantly and reached the highest values at the withering period. The NDF, ADF and lignin concentrations of $H$. scoparium were the lowest at vegetative period and in- 
creased with growth period; for $H$. laeve, the lowest NDF concentration was at vegetative period, whereas the lowest ADF and lignin concentration were at post-fruiting period. According to $\mathrm{CP}$ and fibrous portion, the nutritive values of the five shrubs at the post-fruiting period were much higher over the whole growing period.

The decrease in CP concentrations with growth period of the five shrubs in the present study agreed with the earlier findings [8,12-13]. Neutral-detergent fiber, aciddetergent fiber and lignin concentrations of $H$. scoparium and $H$. laeve increased gradually and were consistent with the general variation law of forages [22]. In contrast, for C. intermedia, C. korshinskii and S. psammophyla, Neutral-detergent fiber, acid-detergent fiber and lignin concentrations decreased before the post-fruiting period and were reversed to general variation law of forages. This could be explained in terms of a lower leaf to shoot ratio at the early growing stage. At the beginning of growing stage, their leaves were very few and small, for $S$. psammophyla, it even bloomed before leaves emerged; for $C$. intermedia and C. korshinskii, they began budding while leaves emerged. In addition, most shoots are old at the early stage. With growing, the ratio of current annual young shoots and leaves increased and resulted in decreasing trends of NDF, ADF and lignin concentrations before the post-fruiting period.

\subsection{The Comprehensive Evaluation of Feeding Value of the Five Shrubs at the Post-Fruiting Period}

The results of chemical composition at the post-fruit- ing period, preference, in vitro DM and OM digestibility and comprehensive evaluation value (EV) are presented in Table 2. Chemical composition of the five shrubs were significantly different $(\mathrm{p}<0.05)$. The CP concentration of $C$. intermedia was the highest and only $0.89 \%$ lower than that of M. Sativa; the CP concentration of $S$. psammophylla was the lowest, but significantly higher than that of cornstalk. The NDF, ADF and lignin concentrations of $H$. laeve and $C$. intermedia were much lower, those of $H$. scoparium were moderate and those of $C$. korshinskii and S. psammophylla were much higher. Fibrous matter concentrations of the 5 shrubs were significantly higher than those of $M$. sativa, NDF, ADF concentrations were obviously lower than those of cornstalk and $A$. splendens and lignin concentrations were significantly higher than those of cornstalk and $A$. splendens.

The order of preference indices at the post-fruiting period was high in order $C$. intermedia, $H$. scoparium, $S$. psammophylla, H. Laeve, and C. korshinskii. It was revealed by investigation that sheep and goats all like eating the five shrubs when they were at the post-fruiting period in late autumn. At this time, $C$. intermedia and $H$. scoparium were eaten best by sheep, $H$. laeve and $S$. psammophylla were better, but $C$. Korshinskii was much worse. Preference indices of the five shrubs were all significantly lower than that of $M$. sativa and higher than that of cornstalk $(\mathrm{p}<0.05)$.

In vitro dry matter digestibility and in vitro organic matter digestibility of $C$. intermedia were the highest with the value of $682.0 \mathrm{~g} \cdot \mathrm{kg}^{-1}$ and $681.3 \mathrm{~g} \cdot \mathrm{kg}^{-1}$ respectively, and only exceeded by those of M. Sativa. Those of

Table 2. Chemical composition, preference, in vitro digestibility and Evaluation value of the five shrubs at the post-fruiting period.

\begin{tabular}{|c|c|c|c|c|c|c|c|c|}
\hline parameter & $\begin{array}{l}\text { Caragana } \\
\text { intermedia }\end{array}$ & $\begin{array}{l}\text { Caragana } \\
\text { korshinskii }\end{array}$ & $\begin{array}{c}\text { Hedysarum } \\
\text { scoparium }\end{array}$ & $\begin{array}{l}\text { Hedysrum } \\
\text { laeve }\end{array}$ & $\begin{array}{c}\text { Salix } \\
\text { psammophyla }\end{array}$ & $\begin{array}{l}\text { Medicago } \\
\text { sativa }\end{array}$ & $\begin{array}{c}\text { Achnatherum } \\
\text { splendens }\end{array}$ & $\begin{array}{l}\text { Stalks of } \\
\text { Zea mays }\end{array}$ \\
\hline $\begin{array}{c}\mathrm{CP} \\
\left(\mathrm{g} \cdot \mathrm{kg}^{-1} \mathrm{DM}\right)\end{array}$ & $187.0 \pm 4.9^{\mathrm{a}}$ & $132.5 \pm 3.2^{\mathrm{b}}$ & $113.0 \pm 3.9^{c}$ & $128.8 \pm 6.3 b$ & $71.4 \pm 3.4^{\mathrm{d}}$ & $195.9 \pm 4.8^{\mathrm{a}}$ & $104.8 \pm 3.9^{c}$ & $34.5 \pm 1.0^{\mathrm{e}}$ \\
\hline $\begin{array}{c}\mathrm{NDF} \\
\left(\mathrm{g} \cdot \mathrm{kg}^{-1} \mathrm{DM}\right)\end{array}$ & $418.9 \pm 14.0^{\mathrm{d}}$ & $528.9 \pm 15.8^{\mathrm{c}}$ & $481.7 \pm 14.9^{\mathrm{cd}}$ & $417.8 \pm 18.5^{\mathrm{d}}$ & $527.7 \pm 13.6^{\mathrm{c}}$ & $324.3 \pm 10.2^{\mathrm{f}}$ & $697.3 \pm 14.9^{b}$ & $809.0 \pm 21.9^{a}$ \\
\hline $\begin{array}{c}\mathrm{ADF} \\
\left(\mathrm{g} \cdot \mathrm{kg}^{-1} \mathrm{DM}\right)\end{array}$ & $296.1 \pm 9.6^{\mathrm{cd}}$ & $406.0 \pm 13.4^{b}$ & $331.5 \pm 10.3^{c}$ & $272.9 \pm 9.5^{\mathrm{d}}$ & $423.4 \pm 11.4^{b}$ & $216.7 \pm 10.8^{\mathrm{e}}$ & $433.5 \pm 11.4^{b}$ & $523.4 \pm 18.0^{\mathrm{a}}$ \\
\hline $\begin{array}{c}\underset{\text { Lignin }}{\left(\mathrm{g} \cdot \mathrm{kg}^{-1} \mathrm{DM}\right)}\end{array}$ & $87.7 \pm 2.9^{c}$ & $111.4 \pm 4.0^{\mathrm{b}}$ & $90.4 \pm 3.7^{\mathrm{c}}$ & $78.2 \pm 4.5^{\mathrm{cd}}$ & $165.7 \pm 5.4^{\mathrm{a}}$ & $77.2 \pm 4.8^{\mathrm{cd}}$ & $58.4 \pm 2.6^{\mathrm{e}}$ & $66.9 \pm 4.4^{d}$ \\
\hline $\begin{array}{l}\text { Acceptable } \\
\text { season }\end{array}$ & $\begin{array}{l}\text { autumn, } \\
\text { winter }\end{array}$ & $\begin{array}{l}\text { autumn, } \\
\text { winter }\end{array}$ & $\begin{array}{l}\text { autumn, } \\
\text { winter }\end{array}$ & $\begin{array}{c}\text { autumn, } \\
\text { winter }\end{array}$ & $\begin{array}{l}\text { autumn, } \\
\text { winter }\end{array}$ & $\begin{array}{c}\text { four } \\
\text { season }\end{array}$ & $\begin{array}{l}\text { growing } \\
\text { season }\end{array}$ & $\begin{array}{l}\text { autumn, } \\
\text { winter }\end{array}$ \\
\hline $\begin{array}{l}\text { Preference } \\
\text { index }\end{array}$ & $1.3 \pm 0.1^{b}$ & $0.6 \pm 0.1^{\mathrm{e}}$ & $1.2 \pm 0.1^{\mathrm{bc}}$ & $0.9 \pm 0.1^{\mathrm{d}}$ & $1.1 \pm 0.1^{\mathrm{c}}$ & $1.6 \pm 0.1^{\mathrm{a}}$ & $0.8 \pm 0.1^{\mathrm{d}}$ & $0.3 \pm 0.0^{\mathrm{f}}$ \\
\hline $\begin{array}{c}\text { IVOMD } \\
\left(\mathrm{g} \cdot \mathrm{kg}^{-1} \mathrm{DM}\right)\end{array}$ & $681.3 \pm 6.0^{\mathrm{b}}$ & $621.6 \pm 5.4^{\mathrm{c}}$ & $600.0 \pm 4.3^{\mathrm{d}}$ & $546.6 \pm 5.7^{\mathrm{e}}$ & $504.7 \pm 5.6^{\mathrm{f}}$ & $755.9 \pm 6.5^{\mathrm{a}}$ & $473.0 \pm 5.7^{\mathrm{g}}$ & $425.1 \pm 5.2^{\mathrm{h}}$ \\
\hline $\begin{array}{l}\text { Evaluation } \\
\text { value }(\mathrm{EV})\end{array}$ & $5.5 \pm 0.1^{b}$ & $4.0 \pm 0.1^{\mathrm{de}}$ & $4.8 \pm 0.1^{\mathrm{c}}$ & $4.4 \pm 0.1^{\mathrm{d}}$ & $3.9 \pm 0.1^{\mathrm{de}}$ & $6.6 \pm 0.1^{\mathrm{a}}$ & $3.8 \pm 0.1^{\mathrm{e}}$ & $2.2 \pm 0.1^{\mathrm{f}}$ \\
\hline
\end{tabular}

$\dagger$ Means followed by different letters within a row are significantly different at $\mathrm{p}<0.05$. 
C. korshinskii, H. scoparium and H. laeve were moderate, while those of $S$. psammophylla were the lowest $(\mathrm{p}<$ $0.05)$, but they were all significantly higher than those of A. splendens and cornstalk $(\mathrm{p}<0.05)$.

In the past, the nutritional qualities of psammophyte shrubs have usually been evaluated by adopting single factor or isolated multiple factors [8-12], but these methods were confined greatly in practice. The feeding value of shrubs could not be reflected comprehensively and some important information was probably lost by using these methods. In this paper, we applied fuzzy multifactorial model to evaluate the nutritive values of the five shrubs at the post-fruitng period. Compared with the methods using single or isolated multiple factors, our method emphasized the application of mathematical model, that was, a strictly quantitative approach to the evaluation of the forage shrubs. This model has also been proved to be an efficient tool for the comprehensive evaluation of forages by Wang and Zhu [21].

The evaluation values of the five shrubs from high to low were $C$. intermedia, $H$. scoparium, $H$. laeve, $C$. Korshinskii, and S. psammophylla in sequence. The comprehensive evaluation values for the five shrubs were all lower than that of $M$. sativa. As feedstuffs, the five shrubs were all better than $A$. splendens and cornstalk. According to maximum subordination principle, the feeding value of $C$. intermedia was the highest, that of $H$. scoparium was high and those of $H$. laeve, C. korshinskii and S. psammophylla were moderate.

\section{ACKNOWLEDGEMENTS}

The research was funded by one of fund project for natural science of the Ministry of Science and Technology (30960268) and one of the National Basic Research Program of China (2010CB434805). We wish to thank Yujin Zhang and many staff at the Bureau of Agronomy and Technology in Yanchi, Ningxia for their assistance of sample collection.

\section{REFERENCES}

[1] Wang, L.H. and Yao, H.L. (1995) A summary of the Japanese joint study on $\mathrm{Mu}$ Us desert-practical way to control and to utilize the desert. Journal of Inner Mongolia Forestry College, 17, 1-8.

[2] Chen, Z. and Zhag, X. (1996) Classification and ordination of landscape in the Mu Us sandland. Acta phytoecol Sin, 20, 423-437.

[3] Chi, L.J. (1994) The impact of global change on the dertification in China. Journal of Natural Resources, 9, 289-303.

[4] Zhang, X.S. (1994) The ecological background of the Mu Us sandland and the principles and optimal models for grassland management. Acta phytoecol Sin, 18, 1-16.

[5] Li, X.R., Xiao, H.L., Zhang, J.G. and Wang, X.P. (2004)
Long-term ecosystem effects of sand-binding vegetation in the Tengger Desert, Northern China. Restoration Ecology, 12, 376-390. doi:10.1111/j.1061-2971.2004.00313.x

[6] Stockton, P.H. and Gillette, D.A. (1990) Field measurement of the sheltering effect of vegetation on erodible land surface. Land Degradation and Rehabilitation, 2, 77-85. doi:10.1002/ldr.3400020202

[7] Li, C.L. and Chen, M.J. (1995) Research progress and trend of shrub feed plans. Heilongjiang Journal of Animal Science and Veterinary Medicine, 6, 18-21.

[8] Wang, Y.K., Yan, Y.X. and An, S.Q. (1999) Nutrition of the forage-used psammophyte shrubs in Wulan Buh Desert. Journal of Desert Research, 19, 280-284.

[9] Jiang, Q. (1992) Expoliture and Utilization of Shrubs as feedstuff in south of Ningxia. China Feed, 2, 35.

[10] Nan, B.H. (1992) Excellent feeding shrub in sandy landhedysarum leave. Ningxia Journal of Agriculture and Forestry Science and Technology, 1, 30-32.

[11] Sun, D.X. and Zhou, Z.W. (1995) Economic character analysis of main forage shrubs on sandy land in Ningxia. Journal of Desert Research, 5, 92-95.

[12] Kang, Y., Wang, Z.L., Du, J.C. and Wang, S.J. (2001) The growth trait and nutrition dynamic research of Calligonum mongolicum at artificial culture. Inner Mongolia Prataculture, 1, 6-9.

[13] Ma, X.Z., Zhao, H.Q., Bai, R.Z. and Hou, C.Y. (1997) A study on the nutritive developments of 5 kinds of psammophyte forage shrubs. Journal of Neimenggu Forestry College, 19, 41-44.

[14] Wang, B. (1991) Studies on dynamics of nutrient contents of main psammophyte shrubs in Yanchi-sandy land. Research of Grassland Agriculture System in Yanchi, Science and Technology Publishing Company in Gansu Province, Lanzhou, 46-48.

[15] AOAC (2000) Official methods of analysis, 17th Edition. Association of Official Analytical Chemists, Arlington, Virginia.

[16] Van Soest, P.J., Robertson, J.B. and Lewis, B.A. (1991) Methods for dietary fibre, neutral detergent fibre and non-starch polysaccharides in relation to animal nutrition. Journal of Dairy Science, 74, 3583-3597. doi:10.3168/jds.S0022-0302(91)78551-2

[17] Tilley, J.M. and Terry, R.A. (1963) A two-stage technique for in vitro digestion of forage crop. Grass and Forage Acience, 18, 104-111. doi:10.1111/j.1365-2494.1963.tb00335.x

[18] Loehle, C. and Rittenhouse, R. (1982) An analysis of forage preference indices. Journal of Range Management, 35, 316-319. doi:10.2307/3898309

[19] Chen, Y.Y. (1984) Fuzzy mathematics. Huazhong University of Science and Technology Press, Wuhan, 61- 69.

[20] Gvilamo, P.J. (1987) Fuzzy control. Measo Control, 26, 10.

[21] Wang, D.L. and Zhu, T.C. (1993) Discussion on quantitative method of comprehensive evaluation of forage value. Acta Prataculture Sinica, 2, 33-38. 
[22] Guo, Y.J., Long, R.J., Zhang, D.G. and Chen, J.G. (2001) The seasonal dynamics of nutrient contents in some dominant shrubs and for age herbs on alpine meadow in eastern Qilian mountain, China. Pratacultural Science, 18, 36-39. 